\title{
Subgeneric division of the genus Orcula Held I837 with remarks on Romanian orculid data (Gastropoda, Pulmonata, Orculidae)
}

\author{
Barna Páll-Gergely', Tamás Deli², Atanas Irikov ${ }^{3}$, Josef Harl ${ }^{4}$
}

I Department of Biology, Shinshu University, Matsumoto 390-8621, Japan 2 Békés Megyei Múzeumok Igazgatósága, Békéscsaba, Gyulai u 1. H-5600 3 Department of Ecology and Environmental Conservation, Faculty of Biology, University of Plovdiv, 24 "Tzar Assen" Str., 4000 Plovdiv, Bulgaria 4 Central Research Laboratories, Natural History Museum Vienna, Burgring 7, 1010 Vienna, Austria

Corresponding author: Barna Páll-Gergely (pallgergely2@gmail.com)

Academic editor: Eike Neubert | Received 10 April 2013 | Accepted 10 May 2013 | Published 17 May 2013

Citation: Páll-Gergely B, Deli T, Irikov A, Harl J (2013) Subgeneric division of the genus Orcula Held 1837 with remarks on Romanian orculid data (Gastropoda, Pulmonata, Orculidae). ZooKeys 301: 25-49. doi: 10.3897/zookeys.301.5304

\begin{abstract}
The genital anatomy of Orcula jetschini (Romania), O. zilchi (Bulgaria) and O. wagneri (Albania) is described. Based on anatomical features (morphology of the penial caecum), shell characters (sculpture and shape) and unpublished molecular data, the genus Orcula is subdivided into three subgenera. O. zilchi was classified within the monotypic subgenus Orcula (Hausdorfia) subgen. n.; O. jetschini, O. wagneri and O. schmidtii were classified to Orcula (Illyriobanatica) subgen. n. (type species: Pupa Schmidtii), whereas the other Orcula species remain in the nominotypical subgenus. Orcula (Hausdorfia) is known from South-Eastern Bulgaria and North-Western Turkey, Orcula (Illyriobanatica) inhabits Western Romania, North-Western Greece, Albania, Macedonia, Kosovo and Montenegro. The nine species of Orcula (Orcula) are known mainly from the Alps and the Western Carpathians (from Eastern France to Eastern Hungary and Slovakia).

The occurrence of only one Orcula species, namely O. jetschini is verified from Romania. Available information suggests that data on the Romanian occurrence of Orcula dolium and O. gularis were based on wrongly identified specimens. Sphyradium dobrogicum (=Orcula dobrogica) is considered as a synonym of $S$. doliolum.
\end{abstract}

\section{Keywords}

Anatomy, taxonomy, Alpine, Banatic, Illyric distribution

Copyright Barna Pál-Gergely et al. This is an open access article distributed under the terms of the Creative Commons Attribution License 3.0 (CC-BY), which permits unrestricted use, distribution, and reproduction in any medium, provided the original author and source are credited. 


\section{Introduction}

Orcula Held 1837, the type genus of the family Orculidae is a group of small (5-10 $\mathrm{mm}$ ), pulmonate land snails with ovate-cylindrical shells and 3-4 lamellae within the aperture and the body whorl. Taxa are primarily found in mountainous regions in relatively humid habitats, most commonly in deciduous forests. There are at least 50 names described within the genus and 14 of them are considered as valid on species level (Harl et al. 2011). The Alps are inhabited by eight Orcula species, and this area is considered as the centre of the diversity of the genus. The type species, Orcula dolium (Draparnaud 1801), has the widest distribution within the genus, occurring from Eastern France to Eastern Slovakia and North-Eastern Hungary and several subspecies are recognized (Klemm 1967, Gittenberger 1978, Harl et al. 2011). Other Alpine Orcula species have much narrower areas and occur in the Alps of Austria, Italy and Slovenia only. Non-Alpine species include O. jetschini (Kimakowicz 1883) from Romania (Banat, Transylvania, Crişana), O. schmidtii (Küster 1843) from Montenegro, Albania and northwestern Greece, O. wagneri Sturany 1914 from Albania, Macedonia (FYROM) and Kosovo and O. zilchi Urbański 1960 is distributed from South-Western Bulgaria to North-Western Turkey.

The anatomy of the Alpine and the Illyric Orcula species is well-known (see Gittenberger 1978 and Schileyko 2012). On the other hand, the reproductive anatomy of the two Eastern European species (jetschini and zilchi) remained unpublished.

Gittenberger (1978) presented compelling data regarding the utility of the epiphallus and penial caecum (= "Flagellum" or "Penisflagellum") in taxonomic studies in Orcula. Gittenberger (1983) noted that extra-Alpine species had much stronger shell sculpture than Alpine species. These conchological and anatomical data, however, did not provide the resolution required to properly subdivide the genus.

Recently, Schileyko (2012) evaluated the taxonomic positions of most Orcula species. He concluded that the genus can be divided into two groups based on the morphology at the epiphallus-vas deferens transition. The transition is abrupt in $O$. conica (Rossmässler 1837), O. fuchsi Zimmermann 1931, restituta (Westerlund 1887), spoliata (Rossmässler 1837) and $O$. dolium, whereas it is gradual in gularis (Rossmässler 1837), austriaca Zimmermann 1932, tolminensis Wagner 1912, wagneri and schmidtii. It is not possible to assign some $O$. dolium specimens to one group or another. Independent of these two groups, Schileyko (2012) delineated five "clusters" (species groups) on the basis of anatomical and conchological characters (1: conica, 2: fuchsi, 3: dolium (s. 1.) + spoliata, 4: austriaca (s. 1.) + tolminensis + gularis, 5: schmidtii + wagneri). In Schileyko's phylogenetic scheme $O$. conica (unique shell shape and peculiar position of the penial caecum) and $O$. fuchsi (unique structure of the epiphallus) are the most basal members of the genus.

Recently, living specimens of $O$. jetschini and $O$. zilchi were made available for study. Anatomical investigation of these species allowed us to fully evaluate the taxonomic relationships within Orcula. We present data here that establishes subgenera 
within Orcula based on shell and genital characters. These divisions are further supported by unpublished molecular data (Harl et al. in prep.).

Furthermore, we discuss the orculid species reported from Romania. Two species, namely Pupa (Orcula) jetschini Kimakowicz 1883 and Sphyradium dobrogicum Grossu 1986 were originally described from Romania. Two other species (O. dolium and $O$. gularis) were also reported from Romania by Bielz (1863) and later by other authors. Distributions of the last two species (see Welter-Schultes 2012), unreliable data sources and inaccessible or lost voucher material make Romanian occurrence data questionable.

\section{Material and methods}

The comprehensive map (Fig. 9) showing the distribution of Orcula dolium, Alpine endemic Orcula spp., O. schmidtii-wagneri, O. jetschini and O. zilchi were compiled by literature sources (Banak et al 2012, Grossu 1986, Hausdorf 1996, Hlaváć 2002, Klemm 1973, Ložek 2006, Marković et al. 2004; Mitrović 2007, Mitrović and Jovanović 2000, Moine et al. 2005, Negrea 1962, 1966, Pintér and Suara 2004, Vavrova 2009, Páll-Gergely 2010, Stossich 1880, 1899), museum collections (HNHM, MMM, NHMW, SMF) and personal communications: O. Gargominy (France), W. de Mattia (Italy), P. Subai (Greece, Montenegro, France, Germany). Records of shells from deposits of the Tisza River (Pintér and Suara 2004) were excluded because of the unreliability of their origin.

Photographs of several focal planes were made with a Wild Makroskop M420 and a Nikon DS Camera Control Unit DS-L2. The different layers were combined with Helicon Focus 4.75 Pro to obtain one completely focused image.

Shells were directly observed without coating under a low vacuum SEM (Miniscope TM-1000, Hitachi High-Technologies, Tokyo). Teleoconch sculpture was noted on the dorsal or dorsolateral area of the penultimate whorl.

\section{Abbreviations}

HNHM Magyar Természettudományi Múzeum (Budapest, Hungary)

MMM Munkácsy Mihály Múzeum (Békéscsaba, Hungary)

MNINGA Muzeul Naţional de Istorie Naturală "Grigore Antipa" (Bucharest, Romania)

NHMSB Natural History Museum, Sibiu (Romania), Bielz collection

NHMSK Natural History Museum, Sibiu (Romania), Kimakowicz collection

NHMW Naturhistorisches Museum Wien (Vienna, Austria)

SMF Senckenberg Forschungsinstitut und Naturmuseum (Frankfurt am Main, Germany).

SP Collection Péter Subai (Aachen, Germany) 


\section{Results}

\section{Systematics}

\section{Family Orculidae Pilsbry 1918}

\section{Genus Orcula Held 1837}

http://species-id.net/wiki/Orcula

1837 Orcula Held, Isis: 919.

Type species. Pupa dolium Draparnaud 1801, by subsequent designation Gray: 1847: 176.

Diagnosis. Shell yellowish-greenish to dark brown; cylindrical to conical and elongated; $8-10$ weakly convex whorls; sculpture of first $0.5-1.0$ protoconch whorl usually smooth, but may be of fine spiral lines, which may be extremely weak; teleoconch axial sculpture variable, ranging from irregular growth lines to equally spaced, conspicuous radial structure; apertural barriers: one parietal and 1-3 columellar lamellae; palatal side of the aperture smooth or with strong tooth or thickening parallel to the apertural lip; parietal callus weak, subangularis sometimes present; palatalis plicae missing.

Penis cylindrical, penial caecum of variable length and shape; penial appendix absent; interior of penis, epiphallus and caecum with longitudinal folds; retractor muscle attaches to the penis-epiphallus junction on the opposite side of the penial caecum; diverticulum absent; distal part of vas deferens sometimes slightly swollen, entering epiphallus terminally; bursa copulatrix long, club-like.

Habitat. Orcula species occur in humid limestone areas, usually forests, or rocky boulder fields at high altitudes. Animals live under stones, leaf litter or decaying wood, or at the base of large rocks.

Remarks. Detailed anatomical and conchological diagnoses were provided by Gittenberger (1978) and Schileyko (1998). According to Hausdorf (1996), the genera Orcula, Orculella Steenberg 1925 and Schileykula Gittenberger 1983 cannot be distinguished from each other based on conchological characters alone.

Some African genera, such as Fauxulus Schaufuss, Fauxulella Pilsbry and Anisolo$m a$ Ancey have very similar genital tracts but usually possess sinistral shells with several apertural lamellae and denticles (see Schileyko 1998, 2012).

In general, species of Schileykula and Orculella usually inhabit dry limestone areas in the Mediterranean. The only exceptions known are the closely related Orculella bulgarica (Hesse) and Orculella aragonica (Westerlund) which both prefer very humid, marshy stream banks (Garrido et al. 2005, Arrébola et al. 2012).

\section{Subgenus Orcula}

Diagnosis. Shell smoothish with irregular growth lines; apex somewhat conical, not blunt; aperture with 2-3 columellar lamellae; penial caecum simple and usually longer than half the length of the penis; its base often not conspicuously thickened. 


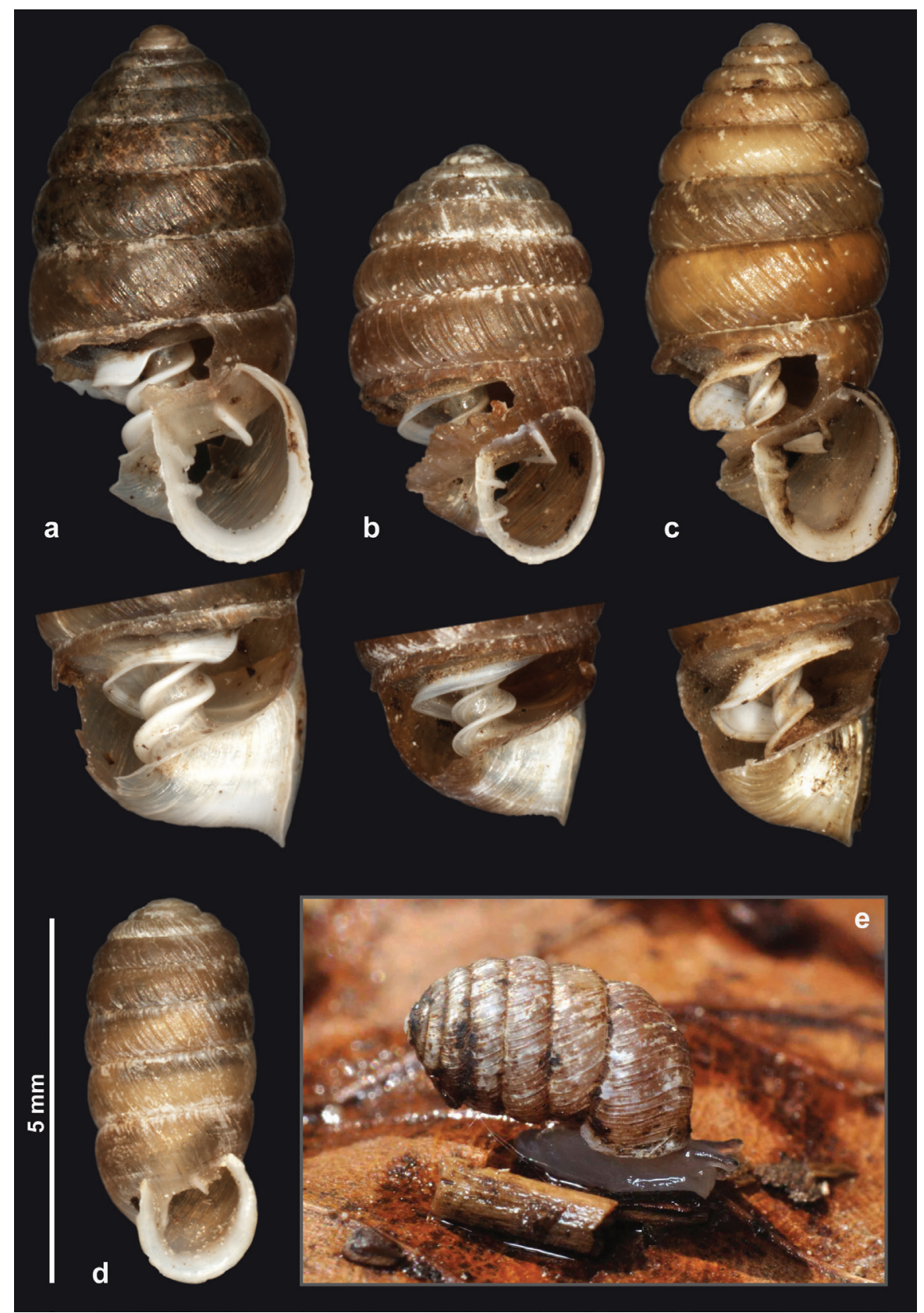

Figure I. Shells and a living specimens of Orculidae species. a Orcula (O.) dolium (Draparnaud 1801), Hungary, Bükk Mts., Farkasnyak, Vöröskő, leg. Németh, L., 21.07.1984 b O. (I.) jetschini (Kimakowicz 1883), Romania, Jud. Bihor, Munții Pădurea Craiului, Şuncuiuş, Valley of Crişul Repede, in front of Peştera Vantului (cave), limestone, leg. Bata, Danyik, Deli, 11.04.2011. c O. (H.) zilchi Urbański 1960, Turkey, Vil. Bursa, between Bozüyük and İnegöl, by the "Mezit 7" bridge, limestone rocks and beach forest next to the road, 580 m, 3955.724'N, 2943.939'E, leg. Páll-Gergely, B., 30.09.2007 d Sphyradium doliolum (Bruguière 1792), Romania, Jud. Tulcea, Forest near the Cocoş Monastery, 145 m, 45⒓835'N, 28²4.415'E Leg: Németh, L. \& Páll-Gergely, B. 26.05.2011 e same locality as b. Photos: J. Harl (a-d) and T. Deli (e). 
Content. austriaca, conica, dolium, fuchsi, gularis, pseudodolium Wagner 1912, restituta, spoliata, tolminensis.

Remarks. The soft anatomy of various Orcula taxa has been described in the following papers: austriaca (Gittenberger 1978, Schileyko 2012), austriaca faueri Klemm 1967 (Gittenberger 1978, Schileyko 2012), austriaca pseudofuchsi Klemm 1967 (Gittenberger 1978, Schileyko 2012), conica (Soós 1925, Gittenberger 1978, Schileyko 2012), dolium (Soós 1917, 1925, Steenberg 1925, Gittenberger 1978, Varga 1986, Grossu 1987, Reischütz 1995, Schileyko 1984, 1998, 2012), dolium brancsikii Clessin 1887 (Reischütz 1995), dolium edita Ehrmann, 1933 (Schileyko 2012), dolium gracilior Zimmermann 1932 (Gittenberger 1978, Schileyko 2012) dolium infima Ehrmann, 1933 (Schileyko 2012), dolium pseudogularis A. J. Wagner, 1912 (Gittenberger 1978), fuchsi (Gittenberger 1978, Schileyko 2012), gularis (Soós 1925; republished by Grossu 1987, Gittenberger 1978, Schileyko 2012), pseudodolium (Gittenberger 1978), restituta (Gittenberger 1978), spoliata (Gittenberger 1978, Schileyko 2012), tolminensis (Gittenberger 1978).

The penial caecum of Orcula (Orcula) restituta is very short compared to other Orcula (Orcula) species, but the shell is similar to that of Orcula (Orcula) gularis. Prior to Klemm (1967), restituta was considered a subspecies of gularis.

A third columellar lamella is rarely present, but can occur in a small percentage of individuals within a population. Brancsik (1888: 84) noted a third columellar fold in only one individual of thousands in each $O$. dolium titan (Brancsik 1888) and $O$. dolium dolium.

Distribution. Most species have limited distributions in the Alps (mainly Austria). O. dolium is widely distributed in Central Europe, in the Alps (eastern France, Switzerland, Southern Germany, Northern Italy, Austria, Slovenia, Northern Croatia, and Slovenia) and the Western Carpathians (Northern Hungary, Slovakia, Eastern Czech Republic). The Croatian records of O. dolium and O. gularis (Stossich 1880, 1899, Zimmermann, 1932) have not been verified by recent investigations.

Our knowledge of the distribution of $O$. dolium is distorted due to misidentified material. Probably all reports of this species (living and fossil) from Spain (e.g. Llamas et al. 1995) refer to Orculella aragonica (see Arrébola et al. 2012). Italian (Toscana) records (Zanchetta et al. 2004, 2006) refer to a yet unknown Orculella species (see photo in Zanchetta et al. 2006). Damjanov and Likharev (1975) reported O. dolium from the Balkan Peninsula, South, Central and West Europe, the Crimea, Western Ukraine, Central Asia, Tunisia, Ethiopia and northen Iran. This distribution is much broader than that of $O$. dolium and probably refers to the distribution of the family Orculidae. Likharev and Rammelmejer (1952) and Sysoev and Schileyko (2009) speculated that $O$. dolium occurs in Ukraine. This supposition has been included in distribution maps (Welter-Schultes, 2012), but to date the taxon's occurrence in Ukraine has not been verified data (Balashov and Gural-Sverlova 2012). Soós (1943) mentioned that during careful collections around Munkács (Mukachevo, southwest Ukraine), Traxler was not able to find the species.

Orcula dolium was more widely distributed during the Pleistocene. The northernmost localities were published by Ložek (2006) (Czech Republic, ca, 30 km north 

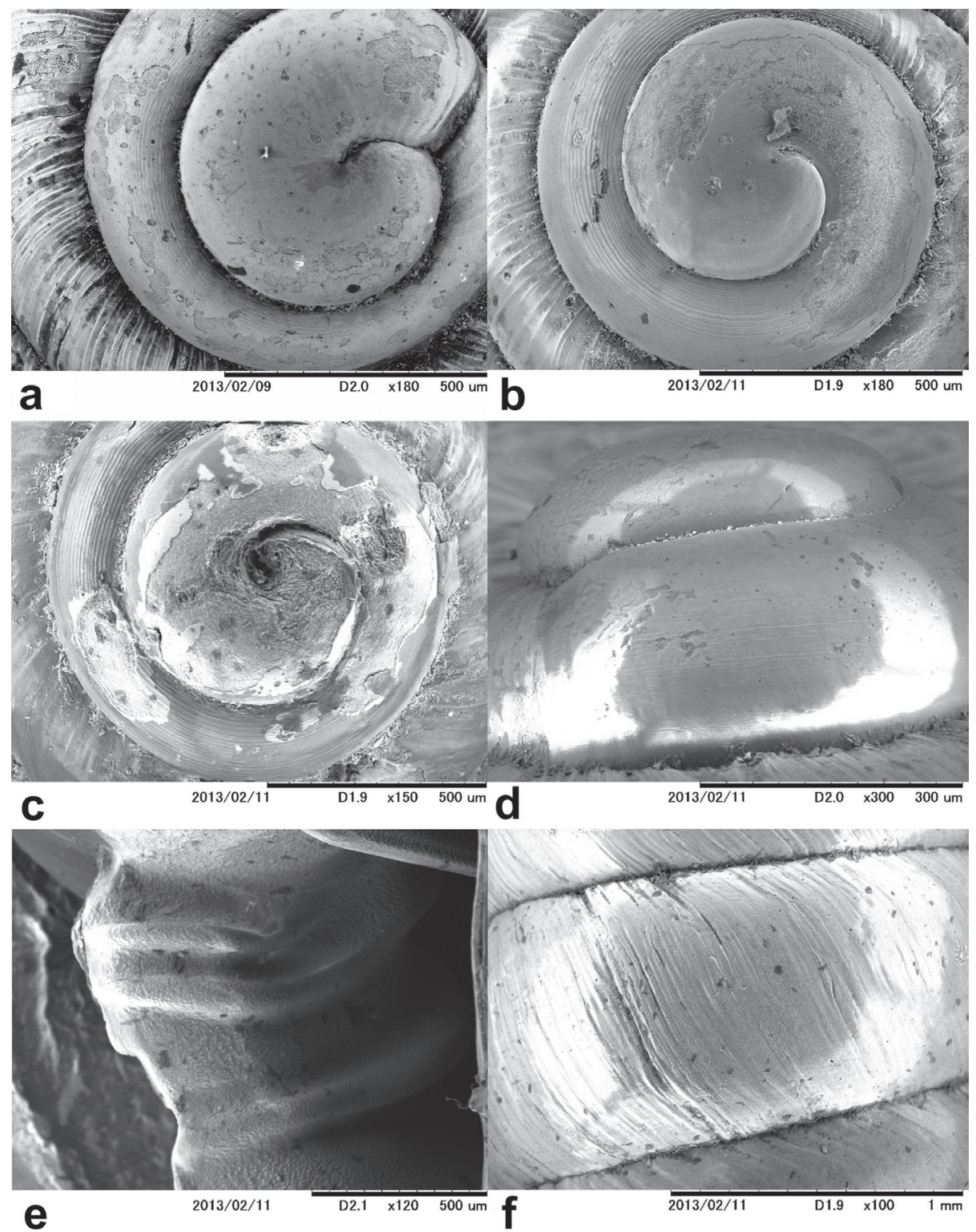

Figure 2. SEM of shells of various Orcula taxa. a protoconch of Orcula (O.) dolium (Draparnaud, 1801), Hungary, Bükk Mts., Farkasnyak, Vöröskő, leg. Németh, L., 21.07.1984 b protoconch of $O$. (I.) schmidtii (Küster 1843), Albania,Mirditë Mts., 1 km NE of Ndërshenë, beneath the Gurit te Çikut peak, $1350 \mathrm{~m}$, $41^{\circ} 49.952$ 'N, 20 06.034'E, leg. Erőss, Fehér, Kontschán, Murányi, 21.10.2002 c protoconch of $O$. $(H$. zilchi Urbański 1960, Turkey, Vil. Bolu, Abant Gölü N, 1030 m, 40³8.756'N, 31²1.531'E, leg: PállGergely, B., 17.05.2006 d protoconch of $O$. (O.) austriaca Zimmermann 1932, Austria: Niederösterreich, Piestingtal, Waldegg, 412 m, 4752.293'N, 16 2.722'E, Duda, M., Haring, E., Harl, J., Kruckenhauser, L., Sattman, H, 10.09.2009 e columellar lamellae of $O$. (H.) zilchi, locality: see figure $\mathbf{2 c} \mathbf{f}$ sculpture of $O$. (O.) tolminensis Wagner 1912, Austria, Kärnten, Karawanken, Eisenkappel, Kupitzklamm, 674 m, 46 27.979'N, 14²36.915'E, leg. Duda, M., Haring, E., Harl, J., Kruckenhauser, L., Sattman, H., 29.07.2009. 
of Prague) and Moine et al. (2005) (Germany, northern Baden-Württemberg). The southernmost locality was reported by Mitrović (2007) from the Serbian Kisiljevo.

Sacco (1897) described Orcula dolium var. pliopedemontana from the middle Pliocene sediments at Ceresole d'Alba (Italy: "Villafranchiano"). The description is unfortunately insufficient and the taxonomic position of this form is uncertain (FerreroMortara et al. 1984, Pilsbry 1922). More recently, Ciangherotti et al (2007) made no mention of the species from the same sediment layers.

\section{Orcula (Illyriobanatica) Páll-Gergely \& Deli, subgen. n.}

Type species. Pupa (Orcula) jetschini M. von Kimakowicz 1883.

Diagnosis. Shell usually with strong axial sculpture (irregular ribs), with two columellar lamellae, apex rather rounded, not attenuate. The penial caecum usually consists of two parts ("tubercles") and its length is less than half that of the penis.

Etymology. The name of this new subgenus refers to its distribution in the Illyrian and Banatic biogeographical regions. It is feminine.

Content. jetschini, schmidtii and wagneri.

Distribution. Montenegro, Albania, Northwestern Greece, Kosovo, Macedonia (O. wagneri and O. schmidtii) and the western part of Romania (O. jetschini).

Remarks. The reproductive anatomy of $O$. schmidtii transversalis (Westerlund 1894) was described by Hausdorf (1987) and Reischütz and Sattmann (1990). According to Hausdorf (1987), the penial caecum of O. schmidtii transversalis is short, but simple. The caecum appears double in the illustration provided by Reischütz and Sattmann (1990).

\section{Orcula (Illyriobanatica) jetschini (Kimakowicz 1883)}

http://species-id.net/wiki/Orcula_jetschini

1863 Pupa (Pupilla) dolium, Bielz, Fauna der Land- und Süsswasser-Mollusken Siebenbürgens, 89 .

1867 Pupilla dolium, - Bielz, Fauna der Land- und Süsswasser-Mollusken Siebenbürgens: 94-95.

1883 Pupa (Orcula) jetschini Kimakowicz, M. von. - Verhandlungen und Mittheilungen..., 33: 44-46.

1922 Orcula jetschini, — Pilsbry: Manual of Conchology...: 5, 17., Plate 2, Fig. 10-11.

['Transylvania, restricted to the southwestern part: Vajda-Hunyad and Bad Gyogy (Kimakowicz), Judenberg near Zalatna (Jickeli). Cerna valley at Mehadia in the Banat (Jetschin)"]

1943 Orcula Jetschini, — Soós: A Kárpát-medence Mollusca faunája: 155-156, plate 6, fig. 18. 

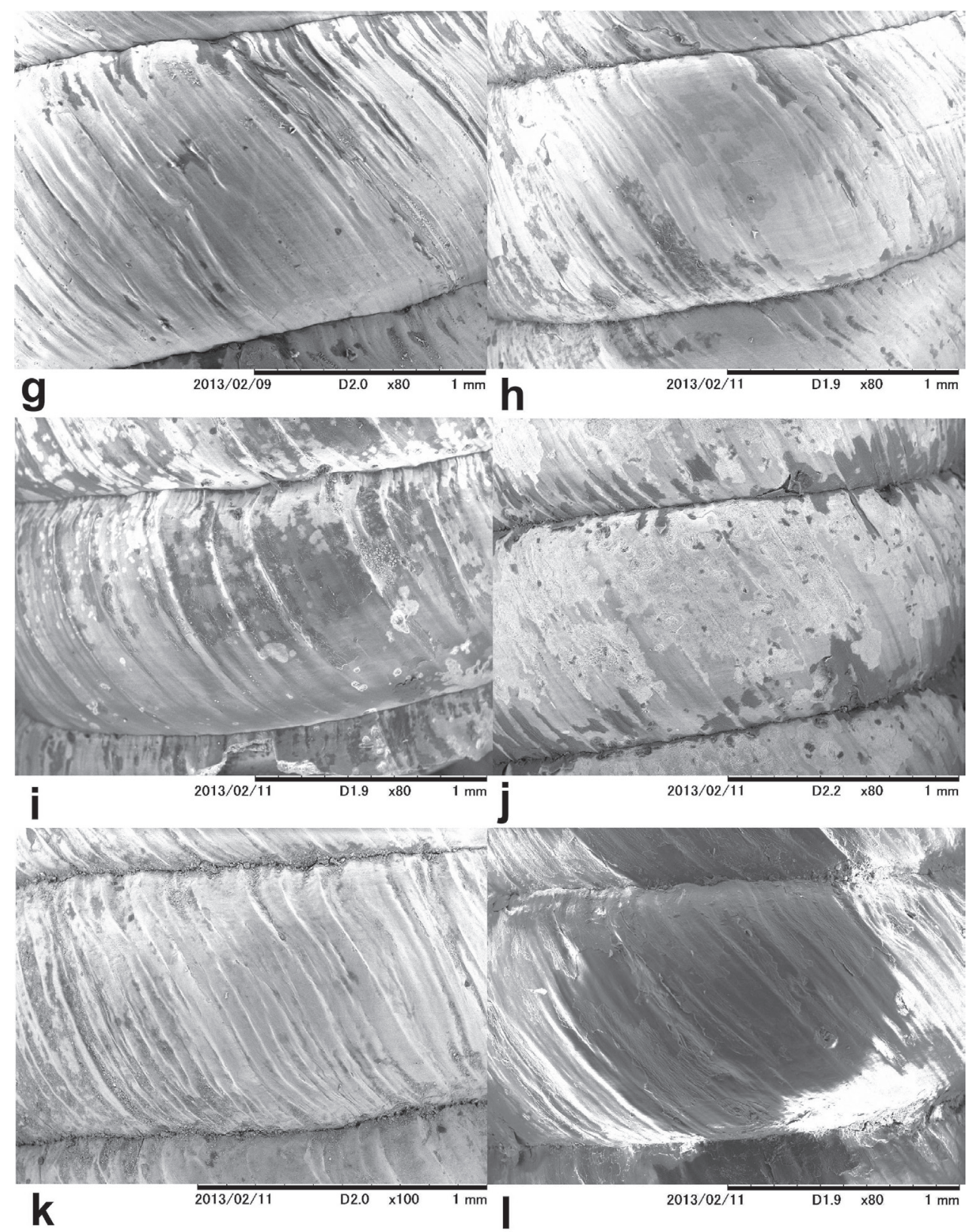

Figure 3. SEM of the shell sculpture of various Orcula taxa. G $O$. (O.) dolium $\mathbf{H} O$. (O.) austriaca $\mathbf{I}$ O. (I.) jetschini, Romania, Jud. Bihor, Munții Pădurea Craiului, Şuncuiuş, Valley of Crişul Repede, in front of Peştera Vantului (cave), limestone, leg. Bata, Danyik, Deli, 11.04.2011. J O. (I.) wagneri Sturany 1914, Albania, Malësia e Madhe, $11 \mathrm{~km}$ from Bogë, north of Tërthorës pass, $1800 \mathrm{~m}, 42^{\circ} 23.537^{\prime} \mathrm{N}$, $19^{\circ} 43.782$ 'E, leg. Erőss, Fehér, Kontschán, Murányi, 20.10.2002. K O. (I.) schmidtii, locality: see figure 2b L $O$. (H.) zilchi, locality: see figure $\mathbf{2 c}$. 
1983 Orcula jetschini, — Kerney et al. Die Landschnecken Nord- und Mitteleuropas: 102-103.

1987 Orcula (Orcula) dolium (partim: citation of Bielz 1863), — Grossu, Gastropoda

Romaniae 2: 221-223.

1987 Orcula (Orcula) jetschini, — Grossu, Gastropoda Romaniae 2.: 223-224.

2011 Orcula jetschini, — Harl et al. Archiv für Molluskenkunde, 140 (2): 184, Plate 4, fig. J.

2012 Orcula jetschini, - Welter-Schultes, European non-marine molluscs...:145.

Material. RO, Jud. Bihor, Munții Pădurea Craiului, Şuncuiuş, Valley of Crişul Repede, in front of Peştera Vantului (cave), limestone, leg.: Bata, Danyik, Deli, 11.04.2011. (anatomically examined); RO, Gyalui-havasok (Munții Gilăului), Runki szakadék (gulch of Runk), leg. Papp, J., 22.07.1959, HNHM 73030/3; RO, Bihar Mts (Munții Apuseni)., Felsőgirda (Gârda de Sus), Ordincus valley., leg. Kovács, Gy., 30.05.1985, HNHM 68284/2; RO, Muntii Bihorului, Baita, Piatra Graitoare, environment of the Crisu Baitei River, leg. Kovács, Gy., 23.08.1974, HNHM 68283/2; Černath. (Chernathal) bls Badern (?) v. Mehadia, leg. Jetschin 1882, NHMSK 4874/5; Forstgra (Forstgartens) bei im Černathal, Banat, leg. Jetschin 1882, NHMSK 4875/2; Klausenburg, Györgyfalvaer Wald, leg. Marzlof 1891, NHMSK 7470/8; Zalathna gegen den Judenberg, leg. Barth 1866-1906, NHMSK 7468/8; Banat, Herkulesbad, leg. Deubel 1895 May-Juni, NHMSK 7469/6; Steierdorf bis zur Höhle Panur, leg. Jetschin 1885, NHMSK 4876/4; Černathal b. Mehadia, leg. Jetschin 1885, NHMSK 4877/4 ("mut. albina"); Gyógybad nächst Broos. Orm. (?) 1887, NHMSK 4873/3; Hideg-Szamos, NHMSB 51/72, 50136-50137; Györgyfalvaer Wald b. Klausenburg, NHMSB 51/82, 50389-50391; Unter-Grohob bei Körösbánya NHMSB 51/92, 50713; Klausenburg, Bükk, NHMSB 51/13, 48225-48226; Klausenburg ?? (not legible on label) Wald, NHMSB 51/23, 48500; RO, Bihor Mts., Valea Boghii (valley), $46^{\circ} 36.610^{\prime} \mathrm{N}, 22^{\circ} 39.542^{\prime} \mathrm{E}$, leg. Páll-Gergely, B. 09.08.2007.; RO, Jud. Bihor, Bălnaca Groşi, cliffs at Bíró Lajos cave., leg. Domokos, T. 18.04.2004, MMM 04503/1; Munții Pădurea Craiului, Şuncuius valley of Crişul-Repede, under shrubs., leg. Domokos, T. \& Deli, T., 08.07.2005, MMM 04505/2; Munții Pădurea Craiului, Şuncuiuş valley of Mişid-brook near brook-Alnetum., leg. Domokos, T.\& Deli, T., 08.07.2005, MMM 04506/3; Munții Apuseni, Gârda de Sus, Ordincus valley., leg. Domokos, T. \& Kovács, Gy., 30.05.1985, MMM 04501/2; Munții Apuseni, Gârda de Sus, Ordincus valley., leg. Domokos, T. \& Deli, T., 30.11.2009, MMM 92488/1; Munții Zărandului, Troaş, Pietroasia, floating debris., leg. Domokos, T., 07.06.2002, MMM 04502/10; Munții Zărandului, Troaş, Valea Galsa floating debris, leg. Domokos, T. et al., 27.05.2005, MMM 04504/11; Jud. Arad, above Obârşia (Munții Metaliferi) (1.9 km W of Arad-Hunedoara board), forest clearing (Corylus), $700 \mathrm{~m}$, leg. Deli, T. \& Domokos, T, 07.03.2007, MMM 90866/2; Jud. Arad, between Pojoga and Căprioara (7 km SE Săvârsin), in gorge-forest, 120 m, leg: Deli, T., Domokos, T., Páll-Gergely, B., Subai, P., 15.04.2007, MMM 91092/2; Jud. Arad, between Pojoga and Căprioara (7 km SE Săvârsin), in gorge-forest, 120 m., leg: Deli, T., 12.06.2007, 


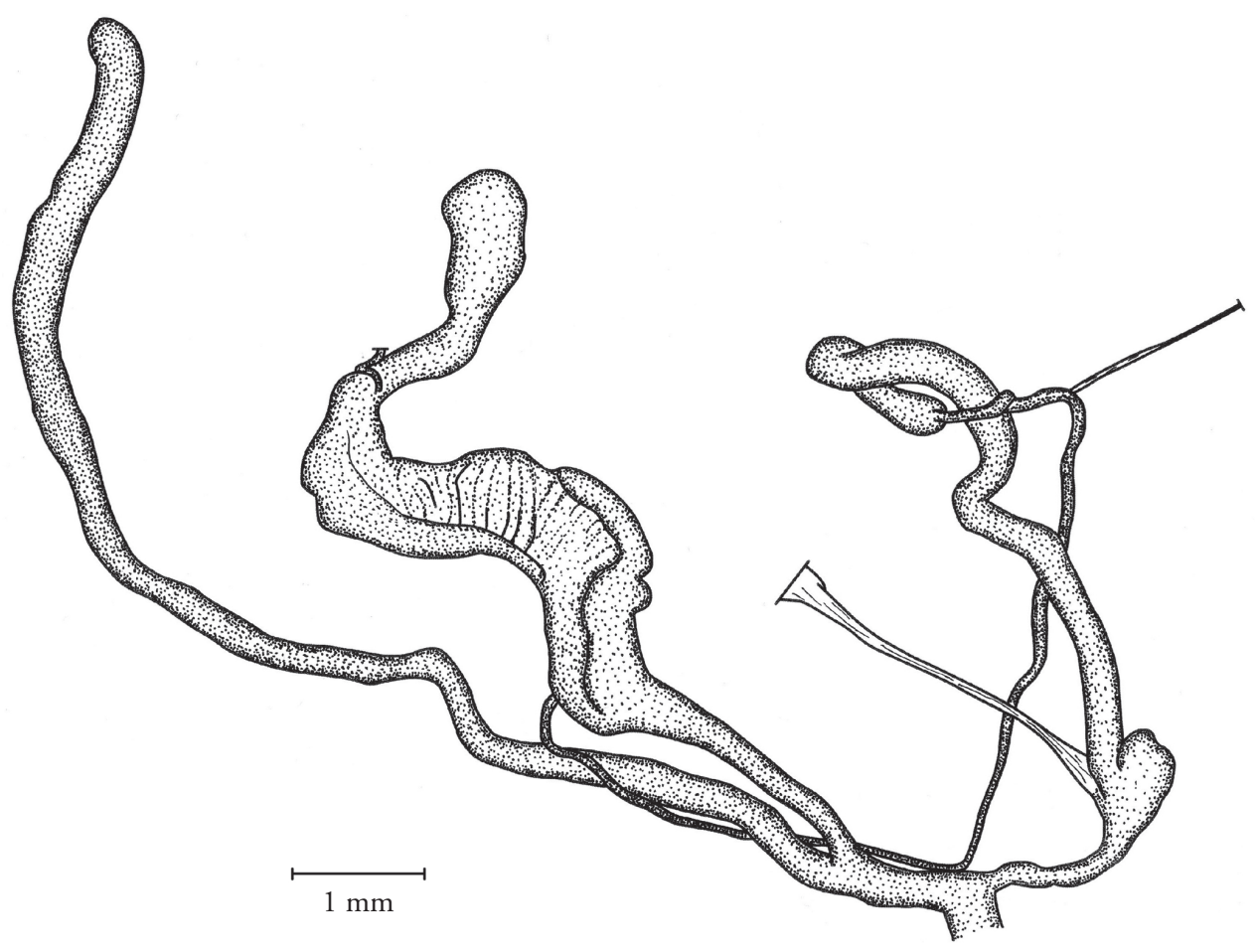

Figure 4. Genital anatomy of $O$. (I.) jetschini (Kimakowicz 1883), locality: see figure $\mathbf{1 b .}$

MMM 90814/1; Jud. Caraş-Severin, between Moldova Nouă and Padina Mate, forest (Fagus, Caprinus, Ruscus) with limestone rocks, 300 m, leg. Boldog, G., Deli, T., Kóra, J., 04.07.2007, MMM 92489/1; Mehadia Mts. (Munții Mehedinți), Cerna valley, Jelărăului gorge, above Băile Herculane, large flotsam deposit, leg. Boldog, G., Deli, T., Kóra, J., 08.07.2007, MMM 92494/6; Munții Mehedinți, Cerna valley, Jelărăului gorge, above Băile Herculane, large flotsam deposit, leg. Deli T., Horváth, É., Lennert, J., Páll-Gergely, B., Subai, P., 04.05.2008, MMM 92490/5; Munții Vâlcan, N Tismana, near Monastery Tismana, bank of Tismana brook, flotsam deposit., leg. Deli, T., Domokos, T., Páll-Gergely, B., Subai, P., 15.04.2007, MMM 92491/1; Munții Vâlcan, Piscuri-valley, 1,4km N Vâlcele (NE Tismana), flotsam deposit., leg. Deli T., Domokos T., Páll-Gergely B., Subai, P., 17.04.2007, MMM 92492/1; Munții Vâlcan, $\mathrm{N}$ of Runcu, Cheile Sohodol, $4.5 \mathrm{~km}$ upstream of the gorge entrance, limestone walls., leg. Boldog, G., Deli, T., Kóra, J., 06.07.2007, MMM 92493/1.

Description of the genitalia. Two specimens were anatomically examined. Penis slim, with the retractor muscle attached at its distal end; penial caecum very small, vestigial, consisting of two "tubercles"; epiphallus very long and cylindrical; there is clear distinction between the vas deferens and the epiphallus; vas deferens long and relatively thick; a slender retractor muscle is attached near the proximal end. Vagina short and thick, but pedunculus relatively long; bursa copulatrix extremely long, with 
the distal end slightly expanded. In one specimen an elongated, simple spermatophore was found with the apical portion slightly thickened.

Distribution. Orcula (I.) jetschini is known only from western part of Romania (Banat, Crişana and Western Transylvania). The Hungarian record (Pintér and Suara 2004) is apparently based on a flotsam specimen so its origin is suspect (Varga, 2009). Negrea (1966) reported the species from Moldova Nouă, which lies close the Serbian border and, therefore, it is expected to occur in Serbia. The Pleistocene distribution of Orcula dolium included the "Požarevac Danube Area" (Mitrović 2007), which is just on the other bank of the Danube River, but temporal and spatial sympatry of $O$. (I.) jetschini and $O$. (O.) dolium is not verified.

Ecology. The species inhabits deciduous forests. It is found most commonly between small stones and leaf litter on the forest floor or under hazelnut (Corylus) bushes. The species is known from non-limestone bedrock, such as the Zarand Mountains.

Conservation status. Least concern (LC) according to IUCN criteria (Fehér 2011).

Remarks. All living specimens found were covered in mud, causing them to appear like tiny grains of soil. The ribbed shell is possibly an adaptation for camouflaging. The photographs herein are of cleaned shells.

\section{Orcula (Illyriobanatica) wagneri Sturany 1914}

http://species-id.net/wiki/Orcula_wagneri

1914 Orcula wagneri Sturany in Sturany and Wagner, — Denkschriften der Kaiserlichen Akademie der Wissenschaften, mathematisch-naturwissenschaftliche Klasse 91: 45, Plate 15, fig. 82b.

2011 Orcula wagneri, — Harl et al., Archiv für Molluskenkunde, 140 (2): 186, Plate 5, fig. A-G, J.

2011 Orcula wagneri, - Audibert, Folia Conchyliologica 14: 21-25. Figure 1: habitat, figure 2, and Figure 1, 2, 4, 5: shells with possible signs of parasites.

2012 Orcula wagneri, — Schileyko, Ruthenica, 22 (2): 152-253, 156, figure 17 (genitalia) 2012 Orcula wagneri, — Welter-Schultes, European non-marine molluscs...:146.

Material. Albania, Bjeshkët e Nemuna (Prokletije Mts), above village Okol, near pass Qafa e Pejës, W slope of Mt. Maja e Popluks, at a spring on limestone, $1660 \mathrm{~m}$, $42^{\circ} 27.343^{\prime} \mathrm{N}, 19^{\circ} 46.478^{\prime} \mathrm{E}$, leg. Barina, Z., Puskás, G., Sárospataki, B., 16.07.2010., HNHM 98841.

Description of the genitalia. One specimen was dissected. Penis cylindrical and slim, with a short, but thick penial caecum, the proximal portion broader than the short and slimmer distal portion; retractor muscle attaches at the penis-epiphallus transition; epiphallus more than twice as long as the penis and much thicker, its transition to the vas deferens is gradual, barely discernable; there is a slim retractor muscle attached to the proximal portion of the epiphallus; proximlal portion of the vas deferens thicker than the distal part. Vagina and free pedunculus extremely 


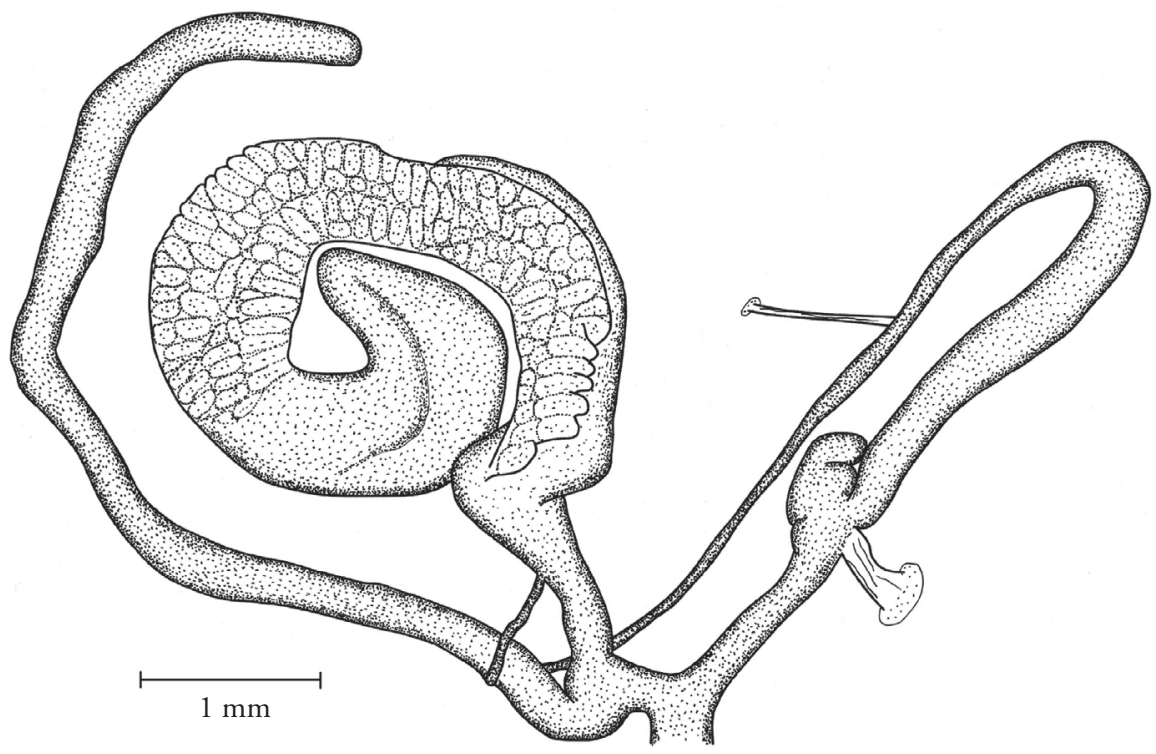

Figure 5. Genital anatomy of $O$. (I.) wagneri. Albania, Bjeshkët e Nemuna (Prokletije Mts), above village Okol, near pass Qafa e Pejës, W slope of Mt. Maja e Popluks, at a spring on limestone, $1660 \mathrm{~m}$, $42^{\circ} 27.343^{\prime} \mathrm{N}, 19^{\circ} 46.478^{\prime} \mathrm{E}$, leg. Barina Z, Puskás G, Sárospataki B, 16.07.2010.

short; bursa copulatrix almost twice as long as the combined length of the penisepiphallus complex.

Conservation status. Orcula (O.) wagneri is listed as Near Threatened (NT), being close to the criteria threshold for Vulnerable (Pall-Gergely 2011a).

Remarks. Our observations on the genitalia agree with that of Schileyko (2012), who investigated the anatomy of O. wagneri from the Tomor Mountains ("Maja e Tomorit Mt., S Albania”). A partially reabsorbed, elongated, spermatophore was located in the bursa copulatrix (Fig. 8B).

\section{Orcula (Hausdorfia) Páll-Gergely \& Irikov, subgen. n.}

Type species. Orcula zilchi Urbański 1960 (by monotypy).

Diagnosis. Shell with conical apex and strong axial sculpture (irregular axial growth lines), with three columellar lamellae (columellar, supracolumellar and one short lamellae above), palatalis reaches its maximum height on the dorsolateral side. Penial caecum very long with thickened base, canal connecting the proximal end of the epiphallus to the penial caecum.

Etymology. The new subgenus is named in honour of Dr Bernhard Hausdorf (University of Hamburg), who first noted the unusual shell characters of Orcula zilchi and questioned its generic status (Hausdorf 1996). It is feminine.

Distribution. See under $O$. (H.) zilchi. 
Remarks. According to Schileyko (2012), the penial caecum of Orcula fuchsi is long and slender, with a thickened base, making it similar in morphology to O. zilchi. However, the characteristic canal connecting the proximal end of the epiphallus with the penial caecum of $O$. zilchi is lacking in $O$. fuchsi. The long caecum of this species is also illustrated by Gittenberger (1978), but its base is not conspicuously thickened. This may vary between populations or during an individual's life history.

\section{Orcula (Hausdorfia) zilchi Urbański 1960}

http://species-id.net/wiki/Orcula_zilchi

1960 Orcula zilchi Urbański, J., Bulletin de la Société des Amis des Sciences et des Let-

tres de Poznan (Série D) 1: 57. ['Am rechten Ufer des Ropotamo, etwa 3 km vor seiner Mündung (etwa $30 \mathrm{~km}$ südlich von Burgas)"'].

1975 Orcula zilchi, — Damjanov and Likharev, Fauna Bulgarica, Gastropoda terrestria, vol. IV: 115.

1996 Orcula (?) zilchi, — Hausdorf, Archiv für Molluskenkunde 125 (1/2): 14, Plate1,

fig. 1. ['Westanatolien: V. Kütahya, Safa 2 km R Domaniç"]

2010 Orcula zilchi, — Páll-Gergely, Zoology in the Middle East, 50: 91.

2011 Orcula zilchi, Harl et al. — Archiv für Molluskenkunde, 140 (2): 186-187, Plate

4, fig. F, G.

2012 Orcula zilchi, — Welter-Schultes, European non-marine molluscs...:146.

Material. Bulgaria, Strandzha Mts., Kondolovo village, 426.150'N, 27³9.896'E, leg. Irikov, A., 28.04.2012. (anatomically examined); Bulgaria, Silkosiya Reserve, near Kosti Village, 23.06.2001, leg., A. Irikov; Turkey, Vil. Bolu, Abant Gölü N, 1030 m, 40³8.756'N, 31 21.531'E, leg. Páll-Gergely, B., 17.05.2006.; Turkey, Vil. Bursa, between Bozüyük and İnegöl, by the "Mezit 7"' bridge, limestone rocks and beach forest next to the road, $580 \mathrm{~m}, 39^{\circ} 55.724^{\prime} \mathrm{N}, 29^{\circ} 43.939^{\prime} \mathrm{E}$, leg. PállGergely, B., 30.09.2007; Bulgaria, floating debris $6 \mathrm{~km} \mathrm{~N}$ of Malko Tarnovo, 210 m, UTM NG 45, 42 $2^{\circ} .028^{\prime} \mathrm{N}, 27^{\circ} 25.698^{\prime} \mathrm{E}$, leg. Dedov \& Subai 8.5.2008, SP 22168/2 (juv.)

Description of the genitalia. Two specimens were dissected. Penis cylindrical, relatively long; retractor muscle short, attaches on the proximal portion; penial caecum very long, with a thickened base and a cylindrical distal portion; an additional canal (?) connects the proximal end of the epiphallus with the penial caecum; epiphallus long, with a thickened distal part; the separation between the vas deferens and epiphallus is distinct; vas deferens relatively thick. Vagina cylindrical and relatively short; bursa copulatrix extremely long with a pointed end.

A developing egg covered with small calcareous crystals was found in the uterus of the figured specimen. In the other specimen, an elongated, simple bursa copulatrix was found with a slightly thickened apical part.

Distribution. South-Eastern Bulgaria and North-Western Turkey. 


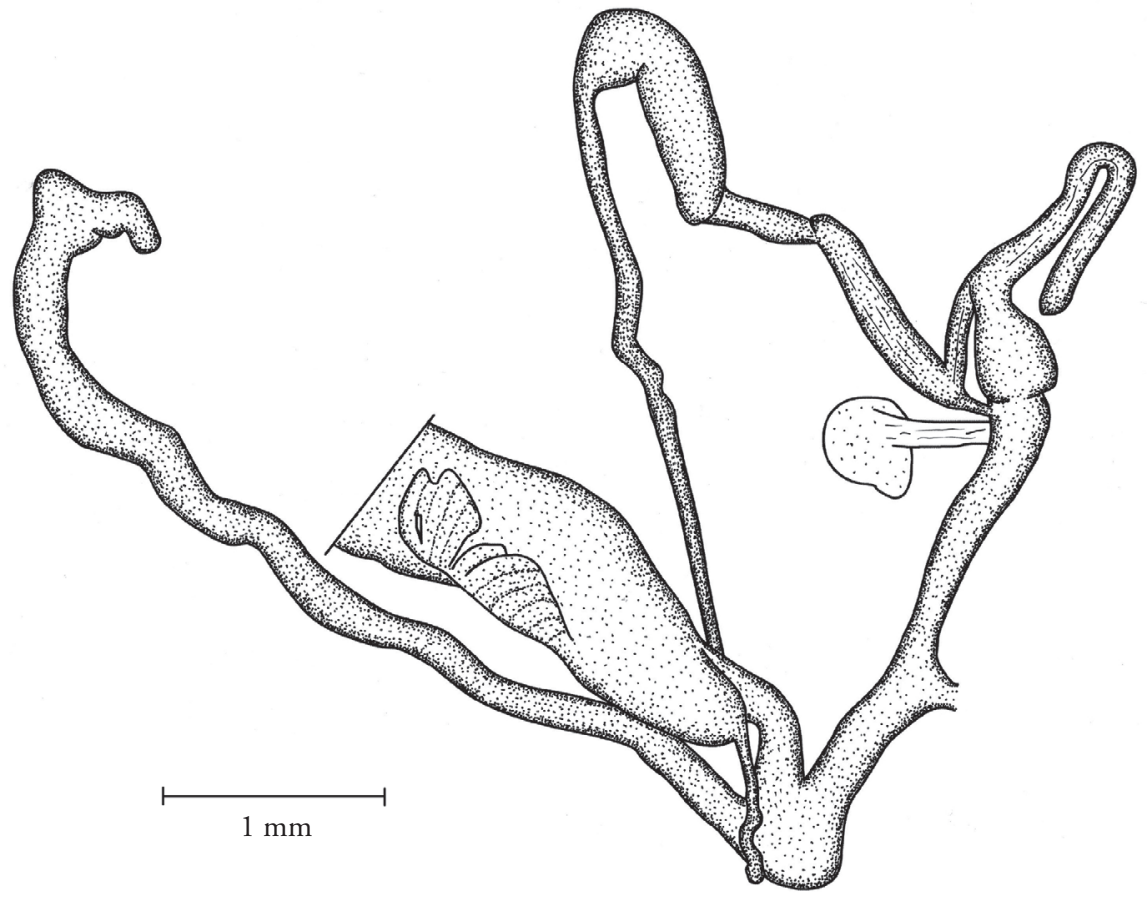

Figure 6. Genital anatomy of $O$. (H.) zilchi Urbański 1960. Bulgaria, Strandzha Mts., Kondolovo village, $42^{\circ} 6.150^{\prime} \mathrm{N}, 27^{\circ} 39.896^{\prime} \mathrm{E}$, leg. Irikov A, 28.04.2012.

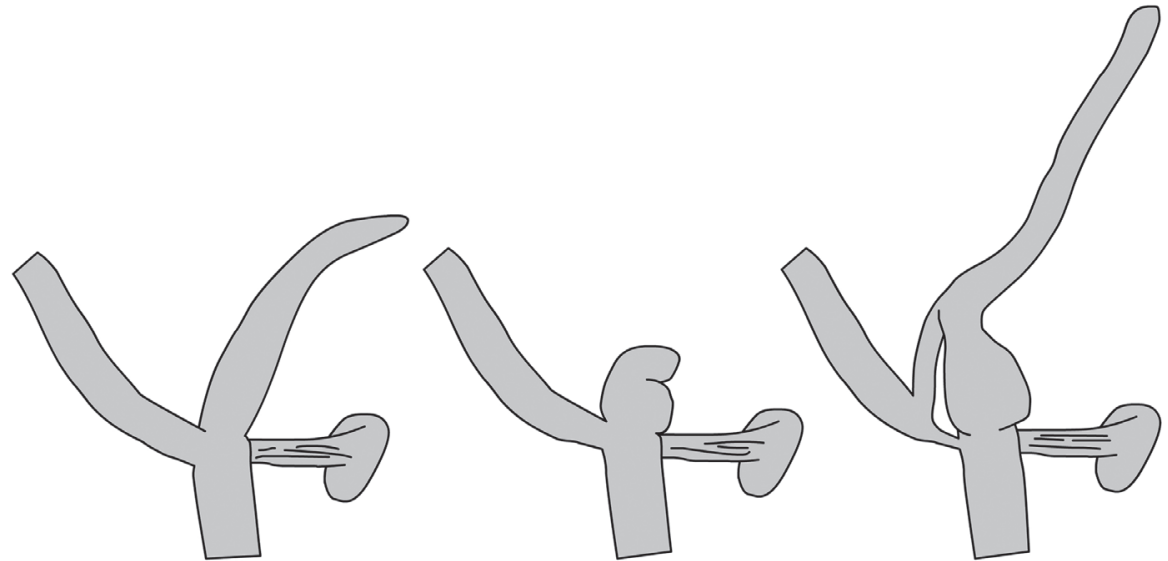

Figure 7. Schematic drawings of the penial caecum of Orcula subgenera. left: Orcula (Orcula), middle: Orcula (Illyriobanatica), right: Orcula (Hausdorfia).

Ecology. The type series (12 shells) of Orcula zilchi was collected by Urbański on the floodplain of the Ropotamo River in leaf litter and under decaying wood. It was found in association with Sphyradium doliolum (Bruguière 1792), Oxychilus deilus rumelicus 


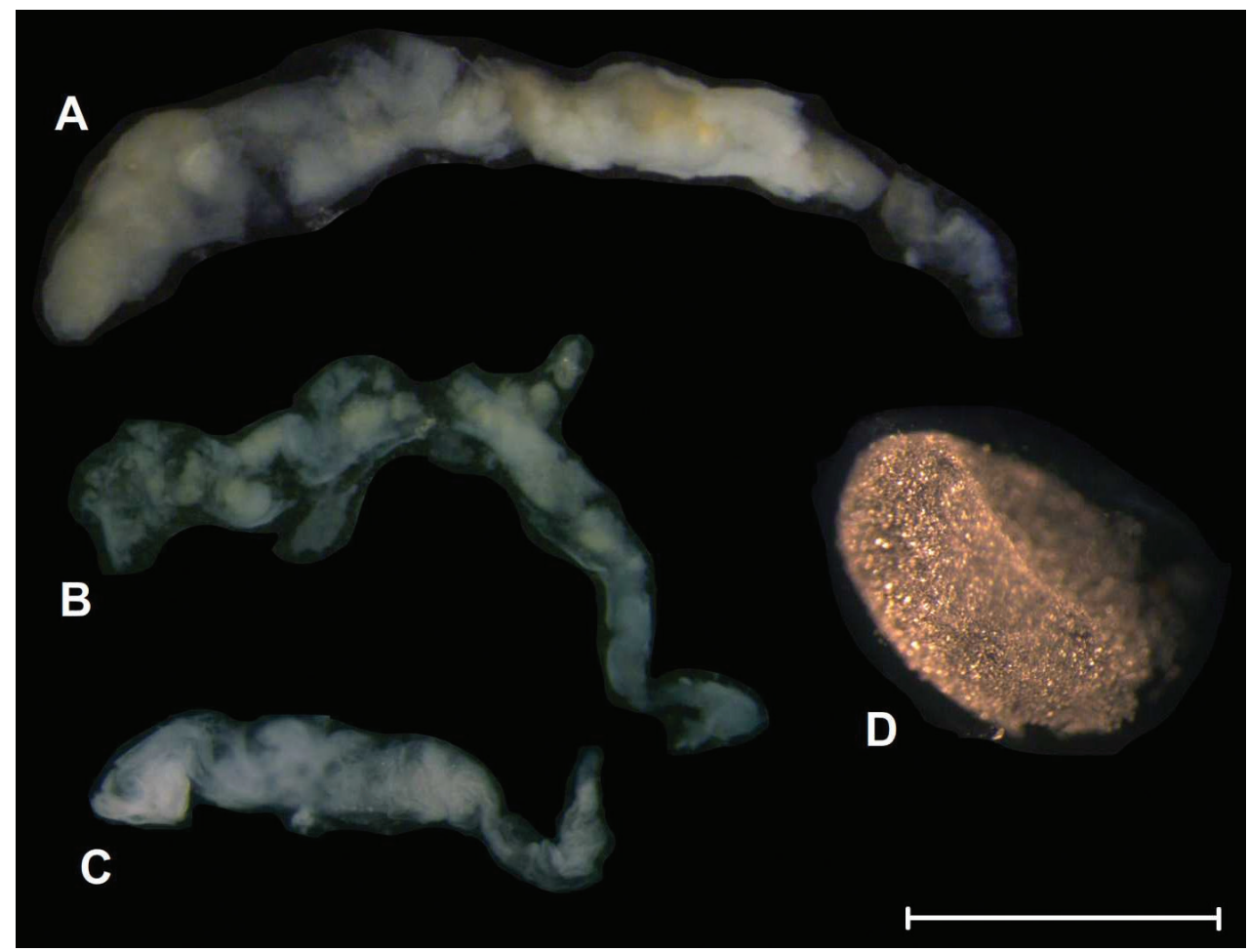

Figure 8. Spermatophores. A $O$. (I.) jetschini (Kimakowicz 1883) B $O$. (I.) wagneri and C $O$. (H.) zilchi D egg. $O$. (H.) zilchi; spermatophore and egg from different individuals. Scale $=1 \mathrm{~mm}$.

Hesse, Laciniaria plicata (Draparnaud), Bulgarica denticulata thessalonica (Rossmässler), Euxina persica paulhessei (Lindholm), E. circumdata (L. Pfeiffer), Cochlodina laminata (Montagu). Atanas Irikov visited the type locality (very humid forest with rocks along the river) on two occasions, with collection time totalling 6-8 hours. Besides O. zilchi he collected all other species previously reported from the Ropotamo area.

We were able to find $O$. zilchi only in deciduous forests. In Bulgaria (near Kondolovo village), living specimens were collected in an oriental beech (Fagus orientalis) forest in shady and moist microhabitats between the leaf litter and soil. These conditions were very similar to the Abant Gölü locality (Turkey). The other Turkish locality (between Bozüyük and İnegöl) was slightly different, with a deciduous forest at the base of a large limestone rock, on a slope covered with smaller stones and larger rocks.

The species is very rare wherever it has been encountered yet, especially in Turkey. On two occasions, in 2007 and 2010, Barna Páll-Gergely spent about 4-5 hours at the locality in vil. Bursa, but found only one specimen in 2007. The other locality (Vil. Bolu) was visited in 2005 and 2006 for similar lengths of time and only one specimen was found in 2006. Atanas Irikov collected 9 living specimens and about 10 empty shells in an hour near Kondolovo in Bulgaria. 


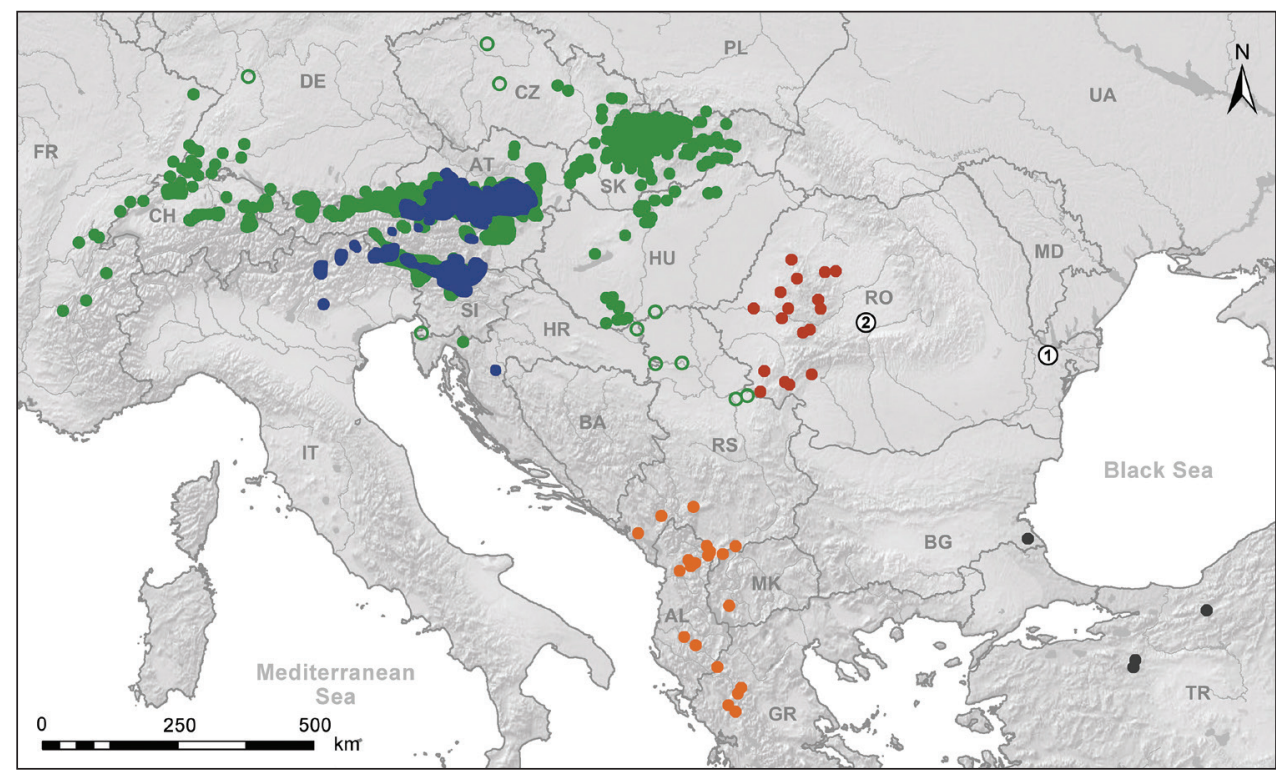

Figure 9. Distribution map of Orcula. Subgenus Orcula: O. (O.) dolium (green) (green circles indicate fossil records), Alpine endemic species (blue); subgenus Illyriobanatica: $O$. (I.) wagneri and $O$. (I.) schmidtii (orange), O. (I.) jetschini (red); subgenus Hausdorfia: O. (H.) zilchi (black). Number 1: type locality of Sphyradium dobrogicum Grossu 1986; Number 2 locality of Orcula gularis (Rossmässler 1837) according to Bielz (1863).

Conservation status. Listed as Vulnerable (V) under IUCN criteria (Pall-Gergely 2011b). Deforestation and disturbance of the forests are the main threat to this species.

Remarks. Two of four living specimens had beetle (possibly drilid beetle) larvae in the body whorl.

The dissected specimens were collected about $23 \mathrm{~km}$ south-southwest of the type locality. The Strandzha Mountains (incl. the collecting site) belongs to the drainage of the Ropotamo River. It is reasonable to suppose that Urbański's population was "washed down" from somewhere in the Strandzha Mts. and settled a temporary subpopulation in the Ropotamo floodplain. This might be a reasonable explanation why A. Irikov could not find this species in the type locality.

\section{Genus Sphyradium Charpentier 1837}

http://species-id.net/wiki/Sphyradium

Sphyradium doliolum (Bruguière 1792)

1792 Bulimus doliolum Bruguière Encyclopédie méthodique: 351.

1986 Sphyradium dobrogicum Grossu, new synonym Travaux du Muséum d'Histoire

Naturelle "Grigore Antipa" 28: 7-13. Bucureşti. [Dobrogea, département de Tulcea, près du Monastère Cocoş de la Forêt Luncavița.] 
1987 Sphyradium dobrogicum, - Grossu: Gastropoda Romaniae 2 ...: 228-230, Fig.

120. ["pădurea Luncavița în apropierea Mănăstirei Cocoş, jud. Tulcea"] 2012 Orcula dobrogica, - Welter-Schultes, European non-marine molluscs...:143.

Remarks. Sphyradium dobrogicum was described based on a single shell. The holotype could not be located in the collection of the Grigore Antipa National Museum of Natural History (Bucharest) during a recent search (2012). It could still be in Grossu's house (Oana Popa, pers. comm., 2011) but, at present, the holotype seems to be lost.

Bank (2011) and Welter-Schultes (2012) assigned the species to Orcula without supporting evidence. S. dobrogicum has a domed apex, a ribbed shell and very weak lamellae (see original description and drawing), indicating that it may represent a dwarf specimen of $S$. doliolum. We visited the type locality of $S$. dobrogicum in 2011 but found only Sphyradium doliolum.

Based on available information we suggest using Sphyradium dobrogicum as a synonym of $S$. doliolum.

\section{Orcula gularis and O. dolium in Romania}

Orcula gularis: Bielz $(1863,1867)$ reported Pupa (Pupilla) gularis from Gușterița, which is presently part of Sibiu. Grossu $(1987,1993)$ cited this record in his account of Sphyradium gularis. Grossu (1986) discussed Bielz's specimens housed in the museum in Sibiu, but specimens were not located in the collection of Bielz in the NHMS. Although Bank (2011) reports the species from Romania, recent authors consider this record as erroneous (Falkner et al 2011) or simply ignore it (Welter-Schultes 2012). Indeed, the occurrence of $O$. gularis in Romania, more than $650 \mathrm{~km}$ from its main distribution area is very unlikely. However, to our knowledge, no one has searched for the species at the respective Romanian locality which was well-defined by Bielz. Nevertheless, despite intensive collecting efforts by competent malacologists over the last 150 years, O. gularis has not been encountered in Transylvania.

$O$. gularis is a very characteristic species with a strong palatal tooth in the aperture. Today, with literature available it is very difficult to misidentify $O$. jetschini as $O . g u$ laris Based on recent available literature, these two species easily can be distinguished from each other. Bielz also had non-Romanian comparative material of $O$. gularis at his disposal: Krain (NHMSB 139634-139635), Oberkrain (NHMSB 139636-139639), Karnthen (NHMSB 139640-139641), Hohewand (NHMSB 139642-139644) and Austria (NHMSB 139645-139646) (Ana Mesaroş, pers. comm.). On the other hand, the understanding of the Orculidae was insufficient at that time. For example, Bielz confused O. jetschini with dolium (see below). Perhaps, a thickening behind the aperture lip of the examined specimens led Bielz to misidentify them as $O$. gularis instead of $O$. jetschini, the species inhabiting that area.

Orcula dolium: Orcula dolium has been recorded from Romania by several authors. Bielz (1863) reported it from "Vajda-Hunyad am Kaczanyas" (Hunedoara), 
"Valea-Ordinkusi bei Skerisora" (Ordâncuşa valley at Scărişoara), "nördlich von Unter-Grohot bei Körösbánya" (Baia de Criș), "Vormága" (Vărmaga) and "Collegiumwald von Nagy-Enyed" (Aiud). In the collection of Bielz (NHMS) we only found the sample from Körösbánya, one sample from "Hideg-Szamos" and more samples from Klausenburg (Cluj Napoca). Kertész (1901) reported O. dolium from a few localities in the Bihor Mountains, and Grossu (1987) most recently from a number of localities, namely from northern Oltenia and the Banat area, and a remote locality in Tulcea County (Luncavița, around the Cocoş Monastery).

Soós (1943) speculated that records of Orcula dolium by Bielz and Kertész (1901) from the Apuseni Mountains should be assigned to O. jetschini. In fact, Bielz revised his original labels from Pupa dolium to jetschini (NHMS).

Two Romanian samples of Grossu in the collection of MNINGA are labelled as O. dolium: MNINGA GST/923, Horezu, Valcea, leg. Grossu (3 shells) and MNINGA 28142, Bucegi, "Sertarul 114", ex Licherdopol ('Orcula dolium var. implicata", 3 shells). Both samples are actually Sphyradium doliolum. We cannot explain the Luncavița locality (see remarks under Sphyradium dobrogicum). We collected near the localities mentioned by Grossu (Oltenia and Banat) and found only O. jetschini. Mitrović (2007) reported O. dolium from the Pleistocene of the Serbian Kostolac, very close to Grossu's localities. It is possible that some of the specimens Grossu examined are Pleistocene fossils, but it seems unlikely that $O$. dolium still lives in the BanatOltenia area in Romania. Soós (1943) marked Torna (southeast Slovakia) as the easternmost locality of $O$. dolium.

\section{Discussion}

In this paper we describe the genitalia of the Eastern European Orcula jetschini and $O$. zilchi for the first time. We also examine and describe the anatomy of $O$. wagneri from a locality that lies $200 \mathrm{~km}$ north of populations examined by Schileyko (2012). This additional information and data published by other authors (mainly Gittenberger 1983 and Schileyko 2012) allows us to review the taxonomic relationships of the entire genus.

The genus can be subdivided into three subgenera (Orcula, Illyriobanatica subgen. n. and Hausdorfia subgen. n.) based on the shell characters and the morphology and size of the penial caecum, which serves as the primary diagnostic character. Unpublished results of molecular phylogenetic analysis (Harl et al. in prep.) of most Orcula species and subspecies indicate the monophyly of these three groups. This subdivision is in good agreement with biogeographic information.

Three species included herein have some shell and anatomical characters which differ from characters used to the features mentioned in the diagnoses of certain subgenera: (1) the shell sculpture of many populations of Orcula (Illyriobanatica) wagneri is almost smooth, which is unusual in the subgenus. (2) The penial caecum of Orcula (Orcula) restituta is very short compared to other species assigned to the subgenus. (3) 
The penial caecum of $O$. (Illyriobanatica) schmidtii transversalis is short, but simple (Hausdorf 1987), not "tuberculated" as the other forms of the subgenus. The caecum of $O$. schmidtii transversalis seems to be double in the illustration of Reischütz and Sattmann (1990).

Based on available literature, the occurrence of Orcula (O.) dolium and $O$. (O.) gularis in Romania is discussed. Most purported Romanian "voucher specimens" are lost or we were unable to examine them. As the published literature is based on possibly misidentified specimens, and the verified distributional ranges of $O$. gularis and $O$. dolium lie far from the Romanian records, we suggest deleting O. gularis and O. dolium from the Romanian faunal list. The occurrence of only one Orcula species, namely $O$. (I.) jetschini is verified from Romania.

\section{Acknowledgements}

We are very grateful to those colleagues who provided access to their museum collections: A. Eschner (NHMW), E. Neubert (NMBE), R. Janssen (SMF), A. Mesaroş (NHMS), Z. Fehér (HNHM), to O. Merkl (HNHM) for determining the beetle larvae found in Orcula zilchi, to T. Gaudényi, P. Subai, V. Štamol, W. de Mattia, I. Fritzsche, O. Gargominy, B. Lecaplain, A. Thomas, A. Wagner, M. Szekeres, O. Popa (MNINGA) for providing information, K. Auffenberg (Florida Museum of Natural History) for correcting the English and for his valuable advices, to Z. Fehér and B. Hausdorf for reviewing the manuscript, to László Németh for help in the field and to the Biodiversity Heritage Library for the multitude of rare literature made available to us (www.biodiversitylibrary.org).

\section{References}

Arrébola J, Razkin O, Gómez-Moliner B, Páll-Gergely B (2012) Redescription of Orculella aragonica (Westerlund 1897), an Iberian species different from O. bulgarica (Hesse 1915) (Gastropoda: Pulmonata: Orculidae). North-Western Journal of Zoology 8 (2): 292-299. http://biozoojournals.3x.ro/nwjz/content/v8n2/nwjz.121126.Arrebola.pdf

Audibert C (2011) De conchyliis balkanicæ III. Un possible cas de castration parasitaire chez Orcula wagneri au mont Žlieb (Crna Gora et Kosovo). Folia Conchyliologica 14: 21-25. http://www.cernuelle.com/file/Folia_Conchyliologica_14.pdf

Balashov I, Gural-Sverlova N (2012) An annotated checklist of the terrestrial molluscs of Ukraine. Journal of Conchology. 41 (1): 91-109.

Banak A, Mandić O, Kovačić M, Pavelić D (2012) Late Pleistocene climate history of the Baranja loess plateau - evidence from the Zmajevac loess-paleosol section (northeastern Croatia). Geologia Croatica, 65 (3): 411-422. http://www.geologia-croatica.hr/ojs/index. php/GC/article/view/GC.2012.30/pdf 
Bank RA (2011) Fauna Europaea: Orcula dobrogica. Fauna Europaea version 2.5, http://www. faunaeur.org/full_results.php?id=429997 (accessed in 02.04.2013)

Bielz EA (1863) Fauna der Land- und Süsswasser-Mollusken Siebenbürgens. Closius, Hermannstadt, 206 pp. http://biodiversitylibrary.org/item/18089\#page/5/mode/1up

Bielz EA (1867) Fauna der Land- und Süsswasser-Mollusken Siebenbürgens. Zweite Auflage. Filtsch, Hermannstadt, 216 pp.

Brancsik K (1888) Pupa brancsikii Clessin keine Species. Jahresheft des Naturwissenschaftlichen Vereins des Trencsiner Komitates 10: 81-85.

Bruguière JG 1792 Encyclopédie méthodique. Histoire naturelle des vers. Tome premier. [ABECON]. Panckoucke, Paris, 1-18. http://biodiversitylibrary.org/item/105173\#page/7/ mode/lup

Charpentier J de (1837) Catalogue des mollusques terrestres et fluviatiles de la Suisse. Formant la seconde partie de la faune Helvétique. Neue Denkschriften der Allgemeinen Schweizerischen Gesellschaft für die Gesammten Naturwissenschaften (Nouveaux Mémoires de la Société Helvétique des Sciences Naturelles) 1 (2): 1-28. http://biodiversitylibrary.org/ item/41729\#page/3/mode/1up

Ciangherotti A, Esu D, Martinetto E, Giuntelli P (2007) The remarkable Middle Pliocene non-marine mollusc record from Ceresole d'Alba, Piedmont, north-west Italy: Biochronology, palaeobiogeography and palaeoecology supported by fossil plants. Geobios 40 (5): 573-587. http://www.em-consulte.com/en/article/129066 doi: 10.1016/j.geobios.2006.10.005

Clessin S (1887) Die Molluskenfauna Österreich-Ungarns und der Schweiz. Bauer \& Raspe, Nürnberg, $858 \mathrm{pp}$.

Damjanov S, Likharev I (1975) Fauna Bulgarica, Gastropoda terrestria, vol. IV. Bulgarian Academy of Sciences, Sofia, 425 pp.

Draparnaud JPR (1801) Tableau des Mollusques Terrestres et Fluviatiles de la France. Renaud; Bossange, Masson \& Besson, Montpellier, Paris, 116 pp. http://biodiversitylibrary.org/ item/90698\#page/11/mode/1up

Ehrmann P (1933) Molluksen (Weichtiere). In: Brohmer P, Ehrmann P, Ulmer G: Die Tierwelt Mitteleuropas. Quelle \& Meyer, Leipzig, 264 pp.

Falkner G, Falkner, M, von Proschwitz T (2011) Orcula gularis. In: IUCN 2012. IUCN Red List of Threatened Species. Version 2012.2. www.iucnredlist.org [accessed 19 January 2013]

Fehér, Z. 2011. Orcula jetschini. In: IUCN 2012. IUCN Red List of Threatened Species. Version 2012.2. www.iucnredlist.org [accessed 19 January 2013] http://www.iucnredlist.org/ details/156965/0

Fehér Z, Gubányi A (2001) The catalogue of the Mollusca Collection of the Hungarian Natural History Museum. Magyar Természettudományi Múzeum, Budapest, 466 pp.

Ferrero Mortara E, Montefameglio L, Novelli M, Opesso G, Pavia G, Tampieri R (1984) Catalogo dei tipi e degli esemplari figurati della collezione Bellardi e Sacco. Parte II. Museo Regionale di Scienze Naturali (Torino), Cataloghi 7: 1-484 
Garrido, J.A., Arrébola, J.R., Bertrand, M. (2005): Extant populations of Orculella bulgarica (Hesse, 1915) in Iberia. Journal of Conchology 38(6): 653-662. http://www.conchsoc. org/node/4754

Gittenberger E (1978) Beiträge zur Kenntnis der Pupillacea VIII. Einiges über Orculidae. Zoologische Verhandelingen 163: 1-44. http://www.repository.naturalis.nl/document/149053

Gittenberger E (1983) Beiträge zur Kenntnis der Pupillacea. IX. Nochmals über Orculidae. Proceedings of the Koninklijke Nederlandse Akademie van Wetenschappen., (C) 86 (3): 325-342.

Gray JE (1847) A list of the genera of recent Mollusca, their synonyms and types. Proceedings of the Zoological Society London, 15: 129-219. http://biodiversitylibrary.org/ item/46217\#page/631/mode/1up

Grossu AV (1986) Nouvelles espèces de la famille Orculidae (Gastropoda, Pulmonata). Travaux du Muséum d'Histoire Naturelle 'Grigore Antipa" 28: 7-13.

Grossu AV (1987) Gastropoda Romaniae 2. Subclasa Pulmonata. I Ordo Basommatophora. II Ordo Stylommatophora, Suprafamiliile: Succinacea, Cochlicopacea, Pupillacea. Editura Litera, Bucureşti, 443 pp.

Grossu AV (1993) The catalogue of the Molluscs from Romania. Travaux du Muséum d'Histoire Naturelle "Grigore Antipa" 33: 291-366.

Harl J, Sattmann H, Schileyko A (2011) Types of the extant taxa of the landsnail genus Orcula Held 1837 (Gastropoda: Stylommatophora: Orculidae). Archiv für Molluskenkunde 140 (2): 149-173.

Hausdorf B (1987) Zum Vorkommen der Gattung Orcula Held in Griechenland (Gastropoda: Orculidae). Archiv für Molluskenkunde 118 (1/3): 51-55.

Hausdorf B (1996) Die Orculidae Asiens (Gastropoda: Stylommatophora). Archiv fur Molluskenkunde 125 (1/2): 1-86.

Held F (1837) Notizen über die Weichthiere Bayerns. Isis (von OKEN), 12: 902-920.

Hlaváč JČ (2002) Molluscan fauna of the Javoříčský Karst (Czech Republic, central Moravia). Malakológiai Tájékoztató 20: 93-105. http://www.matramuzeum.hu/e107_files/public/ docrep/2002_HLAVAC.PDF

Kerney MP, Cameron RAD, Jungbluth JH (1983) Die Landschnecken Nord- und Mitteleuropas: Hamburg \& Berlin, 384 pp.

Kertész M (1901) Biharmegye állatvilága (Fauna). A Jászóvári Premontrei Kanonokrend Nagyváradi Főgimnázium 1900-1901, Nagyvárad.

Kimakowicz M von (1883) Beitrag zur Mollusken-Fauna Siebenbürgens. Verhandlungen und Mittheilungen des Siebenbürgischen Vereins für Naturwissenschaften in Hermannstadt 33: 11-83.

Klemm W (1967) Über ostalpine Orculae. Archiv für Molluskenkunde 96: 101-111.

Klemm W (1973) Die Verbreitung der rezenten Land-Gehäuse-Schnecken in Österreich. Denkschriften der Österreichischen Akademie der Wissenschaften 117: 1-503.

Küster HC (1843-1850) 5. Abtheilungen der Heliceen. Die Gattungen Pupa, Megaspira, Balea und Tornatellina. In: Martini FHW, Chemnitz JH: Systematisches Conchylien-Cabinet, Bauer und Raspe, Nürnberg 1 (15): 1-194.

Likharev IM, Rammelmejer ES (1952) Nazemnye mollyuski fauny SSSR. Opredeliteli po Faune SSSR, Izdavaemye Zoologicheskim Institutom Akademii Nauk SSSR 43. Israel Program for Scientific Translations, Moskva, Leningrad, 511 pp. 
Llamas J, Torres T, Canoira L, García Alonso P, García Cortés A, Hoyos M, Mansilla H, Meyer V, Nodal T (1995) Aminocronología de los depósitos del Pleistoceno Medio de Redueña, Madrid. Geogaceta 17: 43-45. http://www.sociedadgeologica.es/archivos/geogacetas/Geo17/Art11.pdf

Ložek V (2006) Last Glacial paleoenvironments of the West Carpathians in the light of fossil malacofauna. Journal of Geological Sciences 26: 73-84.

Marković SB, Oches EA, Gaudenyi T, Jovanović M, Hambach U, Zöller L, Sümegi P (2004) Palaeoclimate record in the Late Pleistocene loess-paleosol sequence at Miseluk (Vojvodina, Serbia). Quaternaire 15: 361-368. doi: 10.3406/quate.2004.1781

Mitrović B (2007) Pleistocene malacofauna of the Požarevac Danube Area (Ne Serbia). Geološki anali Balkanskoga poluostrva 68: 81-89. http://www.doiserbia.nb.rs/img/ doi/0350-0608/2007/0350-06080701081M.pdf

Mitrović B, Jovanović G (2000) Quaternary malacofauna of Topolovnik and Golubac (northeastern Serbia). Geologica Carpathica 51 (1): 3-6. http://www.geologicacarpathica.sk/src/ abstract.php?id=2000005100010003

Moine O, Rousseau DD, Antoine P (2005) Terrestrial molluscan records of Weichselian Lower to Middle Pleniglacial climatic changes from the Nussloch loess series (Rhine Valley, Germany): the impact of local factors. Boreas 34: 363-380. doi: 10.1080/03009480510013060

Negrea A (1962) Contribuții la studiul moluştelor din peşterile din R.P. Română (nota II). Comunicările Academiei Republicii Populare Române 12 (1): 37-43.

Negrea A (1966) Gasteropodele (Mollusca - Gastropoda) din pesterile Romaniei. Lucrarile Institutul de Speologie 'Emil Racovita" 5: 125-139.

Páll-Gergely B (2010) New and little-known land snails from Turkey (Gastropoda: Pulmonata). Zoology in the Middle East 50: 89-94. http:/www.kasparek-verlag. de/PDF\%20Abstracts/PDF50\%20Abstracts/089-094\%20Pall-Gergely.pdf doi: $10.1080 / 09397140.2010 .10638416$

Páll-Gergely B (2011a) Orcula wagneri. In: IUCN 2012. IUCN Red List of Threatened Species. Version 2012.2. www.iucnredlist.org [accessed 19 January 2013] http://www.iucnredlist.org/details/156852/0

Páll-Gergely B (2011b) Orcula zilchi. In: IUCN 2012. IUCN Red List of Threatened Species. Version 2012.2. www.iucnredlist.org [accessed19 January 2013] http://www.iucnredlist. org/details/156819/0

Pilsbry HA (1916-1918) Manual of Conchology. Second Series: Pulmonata, Vol. 24, Pupillidæ (Gastrocoptinæ). Conchological Department, Academy of Natural Sciences of Philadelphia, Philadelphia, 380 pp.

Pilsbry HA (1922-1926) Manual of Conchology. Vol. XXVII. Pupillidae (Orculinae, Pagodulinae, Acanthinulinae, etc.). Academy of Natural Sciences of Philadelphia, Philadelphia, 369 pp.

Pintér L, Suara R (2004) Magyarországi puhatestűek katalógusa hazai malakológusok gyűjtései alapján. Hungarian Natural History Museum, Budapest, 547 pp.

Reischütz PL (1995) Zur Kenntnis der Genitalmorphologie von Orcula brancsikii Clessin 1887 (Gastropoda: Stylommatophora: Pupillacea). Nachrichtenblatt der Ersten Vorarlberger 
Malakologischen Gesellschaft 3: 30-33. http://www.landesmuseum.at/pdf_frei_remote/ NachErstMalaGes_3_0030-0033.pdf

Reischütz PL, Sattmann H (1990) Beiträge zur Molluskenfauna des Epirus, II. Annalen des Naturhistorischen Museums in Wien 91B: 253-272. http://www.landesmuseum.at/pdf_ frei_remote/ANNA_91B_0253-0272.pdf

Rossmässler EA (1835-1837) Iconographie der Land- und Süßwasser-Mollusken, mit vorzüglicher Berücksichtigung der europäischen noch nicht abgebildeten Arten. Arnold, Dresden and Leipzig, 1-70. http://biodiversitylibrary.org/item/80434\#page/7/mode/1 up Sacco F. (1897). I Molluschi dei terreni terziari del Piemonte e della Liguria. Parte XXII Gasteropoda (fine) (Pleuromariidae, Scissurellidae, Haliotidae, Fissurellidae, Tecturidae, Patellidae, Oocorythidae, Cyclophoridae, Cyclostomidae, Aciculidae, Truncatellidae, Acteonidae, Tornatinidae, Scaphandridae, Bullidae, Cylicnidae, Philinidae, Umbrellidae). Pulmonata (Testacellidae, Limacidae, Vitrinidae, Helicidae, Pupidae, Stenogyridae, Succineidae, Auriculidae, Limnaeidae, Physidae, Siphonaridae). - Amphineura (Chitonidae). Scaphopoda (Dentalidae). Carlo Clausen, Torino, 148 pp. http://biodiversitylibrary.org/ item/46677\#page/9/mode/1 up

Schileyko AA (1984) Terrestrial molluscs of the suborder Pupillina of the USSR fauna (Gastropoda, Pulmonata, Geophila). Fauna USSR, N.S., N. 130. Mollusca. Vol. III, no 3. Nauka, Leningrad, 399 pp. (in Russian).

Schileyko AA (1998) Treatise on Recent Terrestrial Pulmonate Molluscs 1. Achatinellidae, Amastridae, Orculidae, Strobilopsidae, Spelaeodiscidae, Valloniidae, Cochlicopidae, Pupillidae, Chondrinidae, Pyramidulidae. Ruthenica, Supplement 2: 1-127.

Schileyko AA (2012) On the anatomy of Orculidae with special reference to the spermatophores (Gastropoda Pulmonata, Stylommatophora). Ruthenica, 22 (2): 141-158. http:// www.ruthenica.com/documents/Vol22_Schileyko_141-158.pdf

Soós L (1917) Vizsgálatok a magyarországi Pulmonáták rendszertani anatomiája köréből. - Zur systematischen Anatomie der ungarischen Pulmonaten. Annales Historico-Naturales Musei Nationalis Hungarici 15: 1-165.

Soós L (1925) Weitere Beiträge zur Kenntnis des Genitalapparates von Orcula. Archiv für Molluskenkunde 57: 94-99.

Soós L (1943): A Kárpát-medence Mollusca faunája - Budapest: pp 478.

Steenberg CM (1925) Etudes sur l'anatomie et la systématique des maillots (fam. Pupillidae s. lat.). Videnskabelige Meddelelser fra Dansk Naturhistorisk Forening i København 80: 1-215. Stossich A (1880) Il Carso Liburnico. Bollettino della Società Adriatica di Scienze Naturali in Trieste 5: 333-351. http://biodiversitylibrary.org/item/45356\#page/389/mode/1 up

Stossich A (1899) Contribuzione alla fauna malacologica terrestre e fl uviale del territorio di Trieste e in parte delle località contermini. Bollettino della Società Adriatica di Scienze Naturali in Trieste 19: 17-54. http://biodiversitylibrary.org/item/46056\#page/59/mode/1up

Sturany R, Wagner AJ (1914) Über schalentragende Landmollusken aus Albanien und Nachbargebieten. Denkschriften der kaiserlichen Akademie der Wissenschaften, mathematisch-naturwissenschaftliche Klasse 91: 19-138. http://biodiversitylibrary.org/ item/109887\#page/41/mode/1up 
Sysoev A, Schileyko A (2009) Land snails and slugs of Russia and adjacent countries. Pensoft, Sofia, $312 \mathrm{pp}$.

Urbański J (1960) Neue Landschnecken aus Bulgarien (Orculidae u. Pupillidae, Moll. Pulm.) (Systematische, zoogeographische und ökologische Studien über die Mollusken der Balkan-Halbinsel. IV.). Bulletin de la Société des Amis des Sciences et des Lettres de Poznan (Série D) 1: 57-67.

Varga A (1986) A magyarországi Stylommatophorák ivarszervanatómiai vizsgálata. I. Folia Historico Naturalia Musei Matraensis, 11: 71-109. http://www.matramuzeum.hu/e107_ files/public/docrep/vol.11._1986.PDF

Varga A (2009) Régi anyagok a Mátra Múzeum (Gyöngyös) Mollusca-gyüjteményében. Folia Historico Naturalia Musei Matraensis 33: 25-51. http://www.matramuzeum.hu/e107_ files/public/docrep/04_Varga_regi_anyagok.pdf

Vavrova L (2009) Ecosozological evaluation of molluscs of Slovakia by using Geographical Information System (GIS). PhD thesis, Zvolen, Slovakia: Institute of Forest Ecology of the Slovak Academy of Sciences.

Wagner AJ (1912) Beschreibungen neuer Land- und Süßwasserschnecken aus Südösterreich, Kroatien und Bosnien. Verhandlungen der kaiserlich-königlichen Zoologisch-Botanischen Gesellschaft in Wien 62: 246-260. http://biodiversitylibrary.org/item/47784\#page/494/ mode/ 1 up

Welter-Schultes F (2012) European non-marine molluscs, a guide for species identification. Planet Poster Editions, Göttingen, 679 pp.

Westerlund CA (1887) Fauna der in der paläarctischen Region (Europa, Kaukasien, Sibirien, Turan, Persien, Kurdistan, Armenien, Mesopotamien, Kleinasien, Syrien, Arabien, Egypten, Tripolis, Tunesien, Algerien und Marocco) lebenden Binnenconchylien. III. Gen. Buliminus, Sesteria, Pupa, Stenogyra \& Cionella. Håkan Ohlsson, Lund, 183 pp. http://biodiversitylibrary.org/item/41063\#page/615/mode/1up

Westerlund CA (1894) Specilegium malacologicum. Neue Binnen-Conchylien aus der paläarktischen Region. V. Nachrichtsblatt der Deutschen Malakozoologischen Gesellschaft 26 (9/10): 163-177, 190-205. http://biodiversitylibrary.org/item/53280\#page/403/mode/1up

Zanchetta G, Bonadonna FP, Marcolini F, Ciampalini A, Fallick AE, Leone G, Michelucci L (2004) Intra-Tyrrhenian cooling event deduced by a non-marine mollusc assemblage at Villa S. Giorgio (Livorno, Italy). Bollettino della Società Paleontologica Italiana 43: 331-343.

Zanchetta G, Becattini R, Bonadonna FP, Bossio A, Ciampalini A, Colonese A, Dall'Antonia B, Fallick AE, Leone G, Marcolini F, Lippi MM, Michelucci L (2006) Late middle Pleistocene cool non-marine mollusc and small mammal faunas from Livorno (Italy). Rivista Italiana di Paleontologia e Stratigrafia 112: 135-155. http://159.226.74.2/wxdata/En/ Show.asp?id=7381

Zimmermann S (1931) Orcula fuchsi n. sp. Archiv für Molluskenkunde 63: 44-46.

Zimmermann S (1932) Ueber die Verbreitung und die Formen des Genus Orcula Held in den Ostalpen. Zeitschrift für Wissenschaftliche Zoologie, Abteilung B, Archiv für Naturgeschichte (Zeitschrift für Systematische Zoologie) (Neue Folge) 1: 1-56. 